above, but these were only few in number. The International Exhibition in 1862 contained, in the department devoted to the products of the French colonies, a small series of the birds of Martinique, exhibited by M. Bélanger, Director of the Botanical Garden of St. Pierre, in that island.* This is all the published information I have been able to find concerning the birds of Martinique. $\dagger$

12. St. Lucia.-Of this island I believe there is no published ornithological information whatever. The little knowledge of its avifauna which $I$ possess is derived from two sources : first; a few specimens in the Paris Museum obtained by Bonnecourt, a French collector, who visited the island in 1850 and $185 \mathrm{I}$ on his way to Central America; and, secondly, a small series of unpublished coloured drawings in the library of the Zoological Society by Lieut. Tyler, who formerly contributed to the "Proceedings" some notes on the reptiles of that island. $¥$. These drawings although rough and unfinished, are characteristic and mostly recognisable.

I 3. St. Vincent.-St. Vincent was formerly the residence of an energetic and most observant naturalist, the Rev, Lansdown Guilding, F.L.S., who, however, unfortunately died at an early age in this island without having carried out his plans for a fauna of the West Indies. $\$$

Mr. Guilding paid most attention to the invertebrate animals, but his collection contained a certain number of birds, amongst which was a new parrot, described after his decease by Mr. Vigors as Psittacus Guildingii, and probably a native of $\mathrm{St}$. Vincent.

14. Grenada and the Grenadines.-Of the special ornithology of this group nothing is known.

15. Barbados. - The sole authority upon the birds of Barbados is Sir R. Schomburgk's well-known work on that island. If This contains (p. 68I) a list of the birds met with, accompanied by some few remarks. It does not, however, appear that birds attracted much of the author's attention, and more copious notes would be highly desirable.

Although Tobago and Trinidad are geographically reckoned in the Windward division of the Lesser Antilles, they have zoologically, I believe, nothing whatever to do with them. Both have been peopled with life from the adjacent mainland; or, if in the case of Tobago this was not originally the case, it has been overrun with continental species, and, as well as Trinidad, now presents few, if any, traces of Antillean forms. Of the ornithology of both of these islands we have excellent accounts; of that of Tobago by Sir William Jardine, $* *$ from the collections of $\mathrm{Mr}$. Kirk; and of that of Trinidad more recently from the pens of Dr. Léotaud +t and Dr. Finsch.+t

P. L. SClater

\section{REMARKS ON THE CLASSIFICATION OF FRUITS}

TEACHERS and students alike must feel grateful to Dr. Dickson for his "Suggestions on Fruit Clas. sification." The number of names applied to varieties of fruit renders the study most laborious; and as many of the varieties are closely related, the useless names ought at once to be got rid of. One thing strikes me as being a defect in 'Prof. Dickson's classification, and that is the employment of certain of the terms in two different ways. For example he uses the terms Achæne, Berry,

\footnotetext{
* See article on Ornithology in the International Exmibition, Ibis, I862, p. 288 .

+ On animals formerly living in Martinique, but now extinct, see Guyon Compt. Rend. lxiii., p. 589 ( 1866$)$.

$¥$ See P.Z.S. 1849 and 1850 .

See his sketch of his plans, "Zool, Journ.," ii. p. 437. He died in 1832 , II. "History of Barbados," London, I847.

** Annals of Nat. Hist., vols. xviii., xix., xx. (1846-47)

tt Oiseaux de l'ile de la Trinidad, Port of Spain, 1866.

ft See Proc. Zool. Soc., 1870 , p. 552 .
}

and Drupe, in a broad and in a restricted sense. In a broad sense as the name of the genus, if one may so speak, and again uses the same word as a trivial namea species as it were of the genus. The same is also true of his group of capsules, only he thinks a new name might be given to the fruits generally called capsules. It is unfortunate that four out of his five groups should be open to such an objection, and every teacher will at once be able to appreciate the difficulty which the student must have when the same word is used both in a broad and in a restricted sense. The term Schizocarp seems to be a very admirable one, and I do not think the terminology of fruits would be in any way burdened if a few more resembling it were used. It is not without a very great deal of hesitation that I venture to suggest that new terms should be applied to Dr. Dickson's four groups, Capsule, Achæne, Berry, and Drupe. I think that it is much less objectionable to introduce a few more terms, if distinctive and apposite, than resort to the difficult, and at all times confusing, expedient of using these words in a double sense. Taking the word Schizocarp as a type, I venture to suggest the term Achænocarp for the group of Achænes as used by Dr. Dickson, thus avoiding all confusion, and allowing the term Achæne to remain in its restricted sense. Regmacarp I would apply to the group of capsules, using the term capsule for one division of the group. Pyrenocarp seems applicable to the drupes, and Coccocarp to the berries. The derivation of these terms at once explains their application. Achænocarp, from a, privative; chaino, I open ; and karpos, fruit. Regmacarp from regma, a rupture, in allusion to the dehiscence. Pyrenocarp from pyren, the stone of the fruit; and Coccocarp from kokkos, a berry. In using these terms I would employ them in the following manner :-

I. Dry Indehiscent Fruits.

I. Achænocarps. Carpels one or few-seeded.

A. Glans. Pericarp hard and thick.

B. Achæne. Pericarp thin. Including the varieties Caryopsis and Cypsela.

2. Schizocarps. Carpels breaking up into indehiscent portions.

A. Carcerulus. Breaking longitudinally, no forked carpophore.

B. Cremocarp. Breaking longitudinally, a forked carpophore.

C. Lomentum. Breaking transversely.

D. Dischisma. Breaking longitudinally, and then transversely. Fruit of Platystemon. The term, which is new, is derived from dis and schisma, a division.

II. Dry Dehiscent Fruits.

3. Regmacarps.

A. Follicle. Simple, dehisces by one suture.

B. Legume. Simple, dehisces by both sutures.

C. Capsule. Compound, dehisces longitudinally, transversely, or by pores.

D. Regma. Compound, dehisces by rupture along inner angle of lobes.

III. Succulent Indehiscent Fruits.

4. Pyrenocarps. Endocarp indurated.

A. Drupe. One stone, simple or plurilocular.

B. Pome. Two or more-stoned, ovary superior or inferior.

5. Coccocarps. Seeds in a pulp.

A. Uva. Ovary superior, thick or thin skinned.

B. Bacca. Ovary inferior, thick or thin skinned.

IV. Succulent Dehiscent Fruits.

A. Succulent Capsule. e.g., Esculus, Balsamina.

B. Dehiscent Drupe. e.g., Walnut.

C. Dehiscent Berry. eg., Nutmeg, Squirting Cucumber, Nuphar advena.

W. R: MCNAB 